\title{
Freedom of Indifference: Its Metaphysical Credentials According to Crusius
}

\section{Sonja Schierbaum ${ }^{1}$}

Received: 30 August 2018 / Accepted: 14 January 2019 / Published online: 8 February 2019

(c) The Author(s) 2019

\begin{abstract}
In the history of philosophy, voluntarists - that is, philosophers committed to some version of the freedom of indifference-have worried about its metaphysical credentials, but only a few, at least to my knowledge, have attempted to argue for more than its mere existence. Freedom of indifference is the option to choose between opposites in a given situation. In this paper, I present the ambitious attempt of the German pre-Kantian philosopher Christian August Crusius (1715-1775) to argue for the claim that we have freedom of indifference as a matter of hypothetical necessity. The point is that, in his view, there can be no actual world without freedom of indifference. This is not a logical but a metaphysical truth. I argue that a possible (motivational) reason for Crusius's choice to tread this slippery path is that he attempts to bestow some metaphysical dignity on the freedom of indifference. As a consequence, this metaphysical value of freedom of indifference shapes the relation between the divine and free, rational agents in a way that is completely different from a rationalist's conception such as Leibniz's. In this paper, I give a plausible interpretation of a metaphysical argument that has been neglected in the relevant literature.
\end{abstract}

Keywords Freedom of indifference · Voluntarism - Hypothetical necessity · Crusius · Leibniz

\section{Introduction}

If a philosopher is committed to a conception of the freedom of will as the freedom of indifference, that is, the view that the will is the power to will, nill or to do nothing at all with respect to any object, as McCord Adams (1999, 245) puts it with regard to William Ockham (approx. 1288-1345), then this commitment is

Sonja Schierbaum

Sonja.Schierbaum@uni-hamburg.de

1 Philosophisches Seminar, Universität Hamburg, Überseering 35, \#4 Postfach, 22297 Hamburg, Germany 
most likely motivated by a further commitment to the view that human morality is possible only if the will is free in the following way: human agents can be morally praised or blamed for their actions only if they could have acted differently than they actually did. ${ }^{1}$

In the history of philosophy, voluntarists - that is, philosophers committed to some version of the freedom of indifference-have worried about its metaphysical credentials, but only a few, at least to my knowledge, have attempted to argue for more than its mere existence in this world. Ockham, for instance, admits that there is no non-circular argument for establishing the freedom of indifference. However, we can undeniably and "evidently," as he puts it, know from experience that we are free in this way. The freedom of indifference, in his view, is real, albeit only contingently so. ${ }^{2}$ Throughout the history of philosophy, voluntarists have seemed to minimally agree on that.

In this paper, I would like to present the ambitious attempt of the German preKantian philosopher Christian August Crusius (1715-1775) to argue for the claim that it is not contingent that we have freedom of indifference-although it is a contingent truth that the world exists and that we exist. Rather, we have the freedom of indifference as a matter of hypothetical necessity. ${ }^{3}$ The point is that, in his view, there can be no actual world without freedom of indifference. This is not a logical but a metaphysical truth.

I argue that a possible (motivational) reason for Crusius's choice to tread this slippery path is that he wants to bestow some metaphysical dignity on the freedom of indifference by arguing that it is an inevitable, or essential, ingredient of any actual world. As a consequence, this metaphysical value of freedom of indifference shapes the relation between the divine and free, rational agents in a way that differs completely from a rationalist's picture such as Leibniz's. In this paper, I attempt to give a plausible interpretation of a metaphysical argument that has been neglected in the relevant literature. ${ }^{4}$

I proceed as follows: First, I briefly sketch the relevant notion of God (2) before I turn to the different notions of cause (3) and (divine) freedom (4). Against this backdrop, I present and discuss Crusius's argument and the metaphysical reasons for the freedom of indifference (5).

\section{The Notion of God}

Although Leibniz and Crusius hold opposing views on how exactly to conceive of God as a cause, they also partly agree in their notion of God. To see this, let us turn to what Crusius has to say. He writes:

\footnotetext{
${ }^{1}$ In the contemporary discussion, this conception is known as the indeterminacy of free will (cf. Greenspan 2012: 188).

2 Cf. Ockham, Quodlibeta, I, q.16 (OTh IX, 86).

3 More on hypothetical necessity in Sect. 3.

4 Schneewind (1998: 453) mentions the metaphysical argument, but does not discuss it.
} 
...God is an intelligent and necessary, $[\ldots]$ substance, different from the world, being the efficient cause of the world. ${ }^{5}$

By "world" Crusius means

... the whole composed of all finite things (den Inbegriff aller endlichen Dinge), [...] which we are part of. ${ }^{6}$

Leibniz adds how these finite things are ordered:

The sufficient or ultimate reason must lie outside of the succession or series [...] of these contingencies, [...]. And that is why the ultimate reason for things must be a necessary substance, $[\ldots]$; and that is what we call God. $^{7}$

In this passage, Leibniz is literally talking about a reason, not a cause. It is clear from the context, however, that he thereby refers to an efficient cause. He is looking for the cause behind the whole series of "contingencies," that is, contingent things. These things are concrete particulars that can be located spatiotemporally, such as substances (or to use Leibniz's technical term: "monads") and their doings. One can safely assume that "contingencies" are concrete particulars, because in the paragraph preceding the quote, Leibniz refers to "his present writing" as a particular. ${ }^{8}$ In yet another section, Leibniz calls the "“[w]orld" the whole succession and the whole agglomeration of all existent things, ..." Thus, by the "succession or series [...] of contingencies" Leibniz can be taken to mean the whole (or mereological sum) of the concrete particulars that make up the actual world in temporal succession.

These particulars can causally interact. As Crusius puts it, there is a real connection between them. ${ }^{10}$ This connection is either reciprocal or unilateral. ${ }^{11}$ The fact that two particulars $a$ and $b$ are reciprocally connected means that $a$ can causally act upon $b$ and $b$ can causally act upon $a$. When $a$ and $b$ are unilaterally connected, $a$ (or $b$ ) can causally act upon $b$ (or $a$ ), but $b$ (or $a$ ) cannot causally act upon $a$ (or $b$ ). For the present purpose, let us assume that Leibniz and Crusius agree on the following:

\footnotetext{
5 “... Gott ist eine verständige und nothwendige [...] Substanz, welche von der Welt unterschieden, und die wirckende Ursache der Welt ist." Crusius, Entwurf \$205, 349. Note that I omitted Crusius's “explanation" that "necessary" means "eternal" ("nothwendige, d.h. ewige Substanz") due to lack of space. Crusius further discusses these issues in his Entwurf $\$ \$ 123-124,201-203$.

6 "Wir wollen also [...] unter der Welt den ganzen Inbegriff aller endlichen Dinge verstehen, [...] davon wir selbst ein Theil sind." Crusius, Entwurf $\$ 86,348$.

7 "Der zureichende oder letzte Grund muß also außerhalb der Folge oder Reihe dieser einzelnen Kontingenten sein, [...]." Mon. §37. "Und so muß der letzte Grund der Dinge in einer notwendigen Substanz liegen, [...], und dies nennen wir Gott." Leibniz, Mon. §38.

8 "There are an infinite number of shapes and of motions, present and past, which play a part in the efficient cause of my present writing; ..." Leibniz, Mon. $\$ 36$.

9 Leibniz, Théo. I, §8.

10 “... eine Welt heißt eine solche reale Verknüpfung endlicher Dinge, welche nicht selbst wiederum ein Theil von einer andern ist, zu welcher sie vermittelst einer realen Verknüpfung gehörte." This "real connection" is the relation of efficient causality: "So müssen die Dinge in der Welt ineinander wircken können, so daß das eine als eine wirckende Ursache den Zustand des andern verändern kan." Crusius, Entwurf $\$ 359,677$.

11 Cf. Crusius, Entwurf $\$ 359,677$.
} 
(world ${ }_{\text {act }}$ ) If $x$ is the whole of all concrete particulars that can causally interact in temporal succession, then $\mathrm{x}$ is the actual world. ${ }^{12}$

According to both Leibniz and Crusius, God can be described, at least in one sense, as a necessary substance that is the efficient cause of the actual world:

(God) If $\mathrm{x}$ is a necessary substance and $\mathrm{x}$ is the efficient cause of the actual world, then $\mathrm{x}$ is God.

One aspect not being made explicit here is that God is not an efficient cause in the sense that a storm is the cause of a tree's falling down. Rather, being the most intelligent and wisest being, God's efficient causation is an intentional, voluntary action. That means that God has a reason for causing the world, since, according to Leibniz, God "always acts for the best." 13 It is due to this fact that human actions can be modeled on divine action: according to both authors, human subjects are the efficient, yet intelligent and, as Crusius stresses, free causes of their actions. ${ }^{14}$

Leibniz and Crusius agree on the conditions that something must comply with in order to count as God. They also both argue for the necessary existence of God given the existence of the actual world. Their arguments are versions of the so-called cosmological argument. ${ }^{15}$ Leibniz's version of it runs as follows: ${ }^{16}$

1. The cause of any contingent, concrete particular is distinct from that particular.

2. The cause of a complete, conditioned series of all concrete particulars is not part of the series of particulars.

3. Only a necessary substance does not have a cause distinct from itself.

4. Thus, only a necessary substance can be the ultimate cause of a complete, conditioned series of particulars.

5. God is a necessary substance.

6. There is complete, conditioned series of particulars.

$\mathrm{K}$ Therefore, there is God.

Crusius would not object to the overall structure of this argument, since his own version of it is based on the same fundamental idea that the actual, contingent world requires a necessary cause that is distinct from it. Crusius emphasizes the threat of an infinite regress if this cause is not conceived as necessary. He writes:

\footnotetext{
12 To be more accurate: by "prior in time" I mean the following: if $\mathrm{p}_{1}$ is prior in time to $\mathrm{p}_{2}$, then $\mathrm{p}_{1}$ began to exist when $\mathrm{p}_{2}$ did not yet exist. I do not mean that $\mathrm{p}_{1}$ and $\mathrm{p}_{2}$ could not exist simultaneously at any point in time.

13 Cf. Leibniz, Théo. I, §45; Préf.; Theo. I. \$25.

14 I say more on this in Sect. 4.

15 See Crusius, Entwurf \$217, 378-379, "Beweis der Wircklichkeit Gottes aus der Zufälligkeit der Welt”; Leibniz, Mon. \$§37-39. For a discussion of the cosmological argument in Leibniz see Blumenfeld (1995: 353-381).

${ }^{16}$ I offer a paraphrase on the basis of its appearance in Mon. $\S 37-39$.
} 
The contingent has its actuality (Wircklichkeit) ${ }^{17}$ by an efficient cause. In this way, the whole world has its reality by an efficient cause distinct from it. And since one could endlessly infer yet another and another cause if that cause were not necessary, there is a necessary and intelligent cause of the world, that is, there is a God. ${ }^{18}$

Note that although the threat of an infinite regress is formulated in epistemological terms, according to Crusius, it is also ontologically relevant. Leibniz and Crusius seem to agree that this regress would be vicious. There cannot be an infinite regress of efficient causes because the world, being contingent, has not always existed at every past point in time. ${ }^{19}$ Crusius, however, does not agree with Leibniz's notion of a cause underlying the argument.

\section{The Notions of Cause}

At this point, it is necessary to render explicit the version of the Principle of Sufficient Reason (PSR for short) that underlies Leibniz's argument. It concerns concrete particulars having efficient causes. These efficient causes are, as Leibniz says, "determinant." In his Theodicy, Leibniz formulates the principle as follows:

[T]he other principle is that of the determinant reason: it states that nothing ever comes to pass without there being a cause or at least a reason determining it, that is, something to give a priori the reason why it is existent rather than nonexistent, and in this wise rather than in any other. ${ }^{20}$

According to this version, an efficient cause is necessary, that is, it acts necessarily by determining its effect in the following way: if all conditions are met that are required for a cause to be set into operation, the effect cannot fail to be produced, that is, it cannot not exist. Moreover, it can only exist in the way it does and not in any other way. I take the latter to mean that the cause produces exactly one (kind of) effect. $^{21}$ This is why Leibniz also refers to it as a reason that can be given a priori: you can learn what kind of effect a cause produces just by studying its nature or essence.

\footnotetext{
${ }^{17}$ Note that one aspect of the German noun "Wircklichkeit" is that the related adjective "wircklich" connotes something being effective ("wirksam") and not merely "real" being (in contrast to something being merely "potential"). The "reality" of something therefore always implies that the thing, due to its being endued with some powers, can be effective. For this older meaning of "Wircklichkeit" and "wircklich," see Künne (1983: 65-66).

18 "Da nun das Zufällige seine Wircklichkeit durch eine wirckende Ursache haben muß (§31): So hat die ganze Welt ihre Wircklichkeit von einer von ihr unterschiedenen Ursache. Und weil man, dafern sie nicht nothwendig [...] allemal wiederum also schlüssen kan: So giebt es eine von der Welt unterschiedene nothwendige und verständige Ursache der Welt, d.i. es ist ein Gott.” Crusius, Entwurf §217, 378.

${ }^{19}$ Cf. Griffin (2012: 9-33).

${ }^{20}$ Leibniz, Théo. I, §44.

${ }^{21}$ Cf. Crusius, Entwurf $\$ 83,141$.
} 
Crusius admits that Leibniz's principle is valid on this reading. However, he prefers to call this version the "principle of sufficient cause" ("Satz von der zureichenden Ursache"). Like Leibniz, he applies it to concrete particulars that make up the actual world. Crusius writes:

We can conceive of a thing that exists and has formerly not existed only if we concede the existence of yet another [temporarily] prior thing; and it is by means of the latter's sufficient power and effectiveness that the former has been produced. From this flows the rule: everything that begins to exist originates from (entsteht von) another thing that had sufficient power to produce it, and was effective without any prevailing impediment. This (other) thing we call an efficient cause, and if the cause is set into operation, and is sufficient, and not impeded, then the effect necessarily follows. ${ }^{22}$

According to Crusius, a cause acts if all conditions are met that are required for a cause $\mathrm{x}$ to be set into operation and $\mathrm{x}$ is sufficient for producing $\mathrm{y}$ and there is nothing that could prevent $x$ from exerting its power. Then, the effect $y$ necessarily follows, that is, y comes into existence. The necessity involved here is hypothetical (as in Leibniz). By this, Crusius wants to stress that it is only contingently-and not necessarily-true that the conditions for a cause to be set into operation are met. ${ }^{23}$ In other words, the claim that a cause only operates as a matter of hypothetical necessity means that its operating conditions are only contingently met. ${ }^{24}$ It could have been the case that not all of these conditions were actually met on some occasion.

On the face of it, Leibniz would probably agree with Crusius's description of the working of an efficient cause, since in his view "sufficient" just means "determinant." ${ }^{, 2}$ Crusius, however, would not agree with the latter. To see why Crusius denies this, we must bear in mind that — for both Crusius and Leibniz — the notion of a cause involves the basic notion of a power. Although their overall conception of efficient causes is very much alike, it differs in at least one important respect. ${ }^{26}$ Crusius states:

\footnotetext{
22 "Ein Ding, welches ist, und zuvor nicht gewesen ist, können wir ganz und gar nicht denken, ohne nur unter der Bedingung, daß wir zugeben, es sey ein anderes Ding zuvor gewesen, durch dessen zureichende Kraft und Wirkung jenes sey hervorgebracht worden. Daher fließt die Regel: Alles, was zu seyn anfängt, das entsteht von einem andern Dinge, welches zu dessen Hervorbringung zureichende Kraft gehabt, und wirksam gewesen, und nicht verhindert worden ist. Dasselbe Ding aber nennen wir die wirkende Ursache, und wenn selbiges in Wirksamkeit gesetz, und nur zureichend ist, und nicht verhindert wird, so erfolgt daher nothwendig die Wirkung." Crusius, Vom rechten Gebrauche, übers. Krause, §XX, 71-72.

23 "Die hypothetische Nothwendigkeit ist, vermöge welcher etwas zwar bey Setzung gewisser Umstände nicht hat aussenbleiben, oder anders geschehen können, da aber in der Reihe derselben Umstände solche Ursache mit angetroffen werden, welche zu eben der Zeit ihre Wirckung auch hätten unterlasssen oder anders einrichten können.” Crusius, Entwurf §125, 203-204.

24 "Necessitas est [...] hypothetica, quae fundatur [..] in conditionibus non necessariis." Crusius, De usu $\S \mathrm{V}, 17$. For an older, but still valid discussion of this and other modal notions in both Leibniz and Crusius see Burkhardt (1988), see also Adams (1994: 16-20) and Parkinson (1970: 30-35) on the notion of hypothetical necessity in Leibniz.

25 Cf. Leibniz, Théo. I., §2.

26 The notion of a power plays a crucial role for both Crusius and Leibniz. However, at this point, I concentrate on Crusius's account. For Leibniz's conception, see Mon. §48; Principes de la nature et de la grâce $\S \S 2 ; 4$.
} 
The efficient cause, when it produces something, must be endued with a power. The power is the possibility of a conceived thing that inheres in some subject. $^{27}$

What does it mean to say that the power of a thing (a cause) is the possibility of another thing (its effect)? The idea is that if the power of $a$ is actualized, then, as a result of its activity, $b$ is produced. The existence of $b$ depends on the actualization of $a$ 's power.

I will say more about the relation of inherence shortly, which seems to be the same as the relation of subsistence, at least at first sight. Crusius further distinguishes between two kinds of powers - of which only the second is relevant in the present context:

[if] [the power] consists in an inner quality of the thing's essence, then it is called an active power. ${ }^{28}$

The notion of a power is intimately related to the notion of a substance, since powers can only "subsist," as Crusius puts it, within a substance. Elsewhere he states:

[...] this power must always be connected with a substance. One can say that the power is the possibility — connected with a substance A-of a certain thing $\mathrm{B}$, by virtue of which something subsists in A, by which B has or receives its reality. ${ }^{29}$

One should note what "subsistence" and the related verb "to subsist in" mean: roughly speaking, subsistence is an asymmetrical relation of ontological dependence between things that Crusius calls "metaphysical subjects and their properties": if $a$ subsists in $b$, then $b$ is the subject of $a$, and $a$ is the property of $b$. The ontological relation of subsistence is asymmetrical: if $a$ subsists in $b$, then $b$ does not, and cannot, subsist in $a .{ }^{30}$ For instance, if a person has the power to speak English, then this power "subsists in" her, since she is the subject of that property. It would not make

\footnotetext{
27 "Causa efficiens, quando producit quidquam, facultate instructa esse necesse habet. Facultas est possibilitas rei cuiusdam cogitatae subiecto alicui inhaerens." Crusius, De usu 23,199 . The question arises whether "inhere" means the same as "subsist" for Crusius. At first sight, the answer is "probably yes," since the relation of inherence obtains between properties and their subjects, just as the relation of subsistence. But further evidence is needed to give a definite answer.

28 "Vel consistit in interna essentiae rei qualitate, tunc facultas activa dicitur." Crusius, De usu §23, 199-200.

29 "Zuletzt muß dieselbe [Kraft] allezeit an eine Substanz verknüpft seyn. Daher kan man auch sagen, die Kraft sey die an eine Substanz A verknüpfte Möglichkeit eines gewissen Dinges B, vermöge welcher in A etwas subsistiret, wodurch B seine Wircklichkeit hat oder bekommt." Crusius, Entwurf §63, 113.

30 At some point, Crusius seems to use "to subsist in" ("subsistiren in") and "to be in" ("darinnen seyn") interchangeably. More precisely, it seems that "to subsist" in the most general sense means "to be in," with the latter being highly ambiguous. In a stricter sense, when applied to a property, "to subsist in" means something like "to exist as the property of its subject." The question is, of course, what exactly it means to say that a property is "in" its subject. This is not a merely spatial relation, as the example shows.
} 
any sense, however, to say that she, the person, "subsists in" her power to speak English. ${ }^{31}$

Now $a$ and $b$ are what Crusius calls incomplete things. Together, they make up a complete thing, that is, a substance. As Crusius states, "a complete thing, insofar as it is conceived as consisting in a subject and properties, is called a substance." 32 Note that only substances are complete things. To be complete in this sense means to be ontologically independent of any other (created) thing. ${ }^{33}$ Thus, only substances are ontologically independent.

An example may help illustrate the relevant notion of subsistence. ${ }^{34}$ I will paraphrase one of Crusius's own examples. ${ }^{35}$ Crusius asks the reader to imagine a book and to distinguish between its material (cardboard and paper) and its (bricklike) shape. Now, Crusius says that the (brick-like) shape subsists in the material (cardboard and paper). The shape is the property of the material, not the other way around. The material is the subject of the shape. If the material did not exist the way it does, the (brick-like) shape would not exist at all. Yet if the paper and cardboard were torn into pieces, the material would still exist, but with a different shape. More generally, a metaphysical subject can lose a particular property (due to some change) and still exist, whereas a metaphysical property cannot lose its particular subject without ceasing to exist. ${ }^{36}$

Concerning the asymmetry mentioned earlier, Crusius states that since the material of the book can be located spatially, it is in some sense, but not in the same sense, "in" something else. It is in space, as the shape is "in" the material. The merely spatial relation is, of course, not the same as the relation of subsistence. These relations are not on a par, metaphysically speaking. The material is not a property of the space. Therefore, since the material does not subsist in anything else, it can be identified as the metaphysical subject of the shape ${ }^{37}$ The book can also be

\footnotetext{
31 See Crusius, Anweisung $\$ 468,566$ for similar examples.

32 "Ein vollständiges Ding, wie ferne es als aus Subject und Eigenschaften bestehend betrachtet wird, heißt eine Substanz." Crusius, Entwurf $\$ 20,32$.

33 I added "created" here to remind the reader that anything existing in this world in the end depends on God.

34 According to Crusius, the concept of subsistence is simple. Thus, it is not possible to analyze it any further. It should rather be "abstracted from examples": "Der Begriff der Subsistenz ist einfach, und läßt sich also nicht weiter zergliedern, sondern nur aus den Exemplen abstrahiren." Crusius, Entwurf §20, 32.

35 I refer to the following passage: Crusius, Entwurf $\$ 20,31-33$.

36 “... sondern nur diejenigen heissen Determinationen, da das Subject ohne die Eigenschaft nicht seyn kan, ohne daß an deren statt eine andere an ihre Stelle kommt. Z.E. die Fähigkeit Lateinisch zu reden, ist keine Determination der Seele; aber das Lateinisch reden ist wohl eine Determination vom Reden, weil wer redet, und doch nicht Lateinisch redet, doch an statt dessen in einer anderen Sprache reden muß." Crusius, Entwurf $\$ 23,36$.

37 "Allein ieder wird gewahr werden, daß man nicht einerley Art des Darinnenseyns meyne, wenn man sagt, daß die Figur in der Materie subsistire, und daß das Buch in einem Raum existire. Daher ist die Materie des Buchs nicht wiederum eben so in einem andern, wie die Figur in ihr. Sie ist also ein metaphysisches Subject, wieferne man sie von ihren Eigenschaften unterscheidet." Crusius, Entwurf §20, 32.
} 
called a substance insofar as it is possible to conceive of it as something consisting in a metaphysical subject (the material) and its properties (such as its shape). ${ }^{38}$

Applying this sense of "subsistence" to the account of powers and efficient causes, the following picture emerges: an efficient cause produces its effect by means of a power; and the power, as an "inner quality of a thing's essence" can also be described as a property subsisting in a (metaphysical) subject. The metaphysical subject together with its properties is what a substance ultimately consists in. Therefore, substances are efficient causes, at least in the cases that are relevant here. Now, it becomes clear-at least as far as Crusius's conception is concerned-why God is conceived of as a substance: substances, by virtue of being the metaphysical subject of powers they can exert, are efficient causes. Only substances are ontologically independent of any other (created) thing. Of course, God is also independent of any other thing: He is ontologically autonomous, so to speak. It seems that God's perfection partly consists in this fact. What is more relevant in the present context is that Crusius also conceives of God's perfection in terms of His freedom, that is, His free will. The important difference to Leibniz is that, as mentioned earlier, in Crusius's view, not all causes are determinant. Again, I take "determinant" to mean that the cause (by means of exerting its power) necessarily produces exactly one (kind of) effect. The cause produces its effect such that if all conditions for a power to be actualized are met, then the effect necessarily follows. ${ }^{39}$

Now, suppose I raise my arm. Then, I, by exerting my power to raise my arm without any prevailing impediment (my arm was not broken or tied to my back, etc.), was the sufficient cause of that action. In general, an "impediment" to the exertion of a power can be the actualization of another power. But was the cause of it also determinant?

According to Crusius, this depends on whether I also exerted another powera power by means of which I can cause more than one (kind of) effect. ${ }^{40}$ Roughly speaking, this is Crusius's idea of a sufficient, yet non-determinant cause: the substance, insofar as it can exert a power that is apt to produce an effect $F$, or an effect $n o n-F$, or an effect $G$ at one and the same time, is a sufficient, yet not determinant cause. The point is that if the required conditions for this power to be actualized are met, it thereby becomes merely possible, but not hypothetically necessary, that the power is set into operation. ${ }^{41}$ This is why the reason for an action of this power can

\footnotetext{
38 "Wenn man nun das Buch als etwas betrachtet, darinnen so wohl ein Subject ist, als auch Eigenschaften: So nennet man dasselbe eine Substanz." Crusius, Entwurf \$20, 33.

39 To be precise: Crusius claims that a cause (the substance) produces an effect by means of an actualized power, that is, an action. The effect and the action are distinct, as regards either (a) their subject or (b) their quality. Crusius writes: "Die Wirkung (effectus) ist, was durch die Action hervorgebracht wird, und von derselben dem Subject oder den Eigenschaften (qualitate) nach unterschieden ist. Folglich ist zwischen der Wirkung und der wirkenden thätigen Ursache die Action darzwischen, ohne welche es ungereimt zu sagen ist, daß die Wirkung entstehe." Crusius, Ausführliche Abhandlung §23, 67.

40 In this case, the cause of my raising my arm is more complex.

41 "Und von dieser Art muß die Freyheit des menschlichen Willens seyn, daher man den Begriff derselben noch ferner also bestimmen kann, die Freyheit sey der höchste Grad der Thätigkeit in einem Willen, vermöge welcher er eine Wircksamkeit selbst anfangen, richten und wiederum abbrechen kan, ungeachtet dieselbe durch alle dabey erforderliche Bedingungen nicht mehr als möglich gemacht worden." Crusius, Anweisung $\$ 41,50$.
} 
only be given a posteriori, as Crusius notes. ${ }^{42}$ Crusius calls this power "freedom." Only actions involving the actualization of the power of freedom are not hypothetically necessary. Against this backdrop, it is now time to turn to the different conceptions of (divine) freedom. ${ }^{43}$

\section{4 (Divine) Freedom}

According to Crusius, God, as a substance, is the sufficient, yet not determinant cause of the world, since God exerted the power Crusius calls "freedom." It is one of the powers that make up the will. ${ }^{44}$ In general, the will, according to Crusius, is "the power of a mind to act according to its ideas." 45 However, the will is not just one single power but rather a (ordered) bunch of two different kinds of powers, namely a free and a non-free power. ${ }^{46}$ Leibniz rejects this distinction because he rejects Crusius's notion of freedom as a power of the will. Non-free volitions are actualized states of desiring. These states can differ in degree of intensity or strength. ${ }^{47}$ For instance, it is adequate to say that one's desiring $A$ is stronger than one's desiring $B$. Desires, Crusius tells us, are-in most cases - not strong enough for causing us to act in order to satisfy them, and normally, more than one such state is actualized at the same time. ${ }^{48}$ The point is that desires, at least with respect to human substances, can be caused by perceiving or imagining external things, or by thoughts and considerations. Crusius stresses that, as soon as we wake up in the morning, the

\footnotetext{
42 "Denn ob wir sie gleich auch aus einem determinirenden Grunde zu erklären ängstlich wünschen $\S X V I I I[\ldots]$; so leidet doch solches die Natur der Sache selbst nicht, sondern nöthiget uns vielmehr, die Grenzen unseres Verstandes zu erkennen, und, wenn man auf Erklärung dieser Kraft [des freien Willens] kömmt, welche den allerherrlichsten Theil des Ebenbildes des unendlichen Wesens ausmacht, mit der Erkenntniß a posteriori zufrieden zu seyn." Crusius, Ausführliche Abhandlung §42, 117.

${ }^{43}$ For a recent discussion of Crusius's conception of freedom and causation, see Dyck (forthcoming) and Hogan (2009: 363-364).

44 "Dasjenige Wollen, welches man bey eben den Umständen unterlassen, oder auf etwas anderes richten kann, heißt ein freyes Wollen, und die Kraft darzu die Freyheit. Diejenige Anwendung der Freyheit zu einem vorkommenden Falle, wodurch man denselben wirklich will, heißt ein Vorsatz oder Entschluß." Crusius, Anweisung §22, 23.

45 "Ich verstehe unter dem Willen die Kraft eines Geistes, nach seinen Vorstellungen zu handeln." Crusius, Anweisung §2, 4.

46 “... ist der Wille in allen endlichen Geistern eine besondere und von dem Verstande unterschiedene Grundkraft, oder wenn man ganz genau reden will, ein Inbegriff besonderer Grundkräfte, welche man wegen ihres gemeinschaftlichen Wesens unter einem Nahmen zusammen fasset und den Willen nennet, ..." Crusius, Anweisung \$6, 7. Although in this passage, Crusius explicitly refers to the will of "finite minds," the distinction applies to the divine power of will as well. See his Entwurf §276, 499.

47 "Ein Trieb oder Begierde ist ein Wollen, welches auch ohne Vorsatz mit einer Beständigkeit fortdauret. [...] Ob aber gleich iedwede Begierde ein beständ fortdaurendes Bestreben ist, so wircket sie doch, wie die Erfahrung lehret, nicht immer mit einerley Grad der Stärcke. Gemeininglich ist eine Begiere in ihrem natürlichen und fortdaurenden Zustande nicht zureichend, daß sie in die That wircklich ausbrechen könte." Crusius, Anweisung §58, 3.

${ }^{48}$ By "desire" I mean an actual state of desiring.
} 
perception of things actualizes many desires in us. ${ }^{49}$ The actualization of these states is not "up to us": we cannot choose which desires we want to have and which, even more importantly, we do not want to have in the first place. What is up to us, however, is the adoption of a desire as action-guiding. In other words, we can choose among the desires that we do not choose to have. This is the freedom of will that we have. As Crusius states:

Freedom is a power that can only choose one among its many desires; and it chooses to act in accordance with this [desire] or to connect its activity to it. ${ }^{50}$

The key notion here is that of a choice. Crusius literally and somewhat improperly says that the power chooses one of the prevailing desires. However, as we saw above, the power is just the (metaphysical) property, not even the metaphysical subject here. Rather, the metaphysical subject is the mind in which the power of will subsists. The mind, in turn, is identical with the substance. That is, the substance chooses between desires, not the power. For instance, choosing in one and the same situation whether to pursue one's desire for having a piece of cheesecake (which one is craving) or to go for a run instead (which one does not desire so much) is what exerting one's power of freedom amounts to. As Crusius puts it:

Willing is called "free" when it can also be omitted or directed at something different in the same situation, and the power to do so [is called] freedom. The actual use of freedom (that is, the attempt to make real what one wills) is called "intention" or "decision". 51

In general, the following holds:

(Free) A substance $\mathrm{S}$ freely chooses to do $\mathrm{x}$ at $\mathrm{T}_{1}$ if and only if $\mathrm{S}$ chooses to do $\mathrm{x}$ at $\mathrm{T}_{1}$ and $\mathrm{S}$ could have chosen not to do $\mathrm{x}$ at $\mathrm{T}_{1}$ (to omit to do $\mathrm{x}$ ) or to do $\mathrm{y}$ at $\mathrm{T}_{1}{ }^{52}$

One might accuse me of ascribing a notion of human - and not divine-freedom to Crusius. Recall, however, that for both Crusius and Leibniz, human freedom mirrors divine freedom (due to the so-called image thesis). ${ }^{53}$ And Crusius further explains

\footnotetext{
49 "Man siehet hieraus, warum sogleich eine Menge Triebe erreget werden müssen, wenn wir des Morgens aufwachen, weil uns die Dinge, welche wir empfinden, theils selbst reizen, ..." Crusius, Anweisung $\$ 59,75$.

50 "Die Freyheit ist demnach eine Kraft, welche nur unter unsern vielen Begierden eine wehlen kann, nach welcher sie handeln oder mit welcher sie ihre Thätigkeit verknüpffen will.” Ibid. §43, 54 .

51 "Dasjenige Wollen, welches man bey eben den Umständen unterlassen, oder auf etwas anderes richten kann, heißt ein freyes Wollen, und die Kraft darzu die Freyheit. Diejenige Anwendung der Freyheit zu einem vorkommenden Falle, wodurch man denselben wirklich will, heißt ein Vorsatz oder Entschluß." Ibid. §22, 23 .

52 At this point, I leave open what exactly the sameness of situation amounts to. I merely suppose that sameness of time is part of its requirements, but even this might be controversial.

53 The biblical saying that "man is made in the image of God" has been interpreted by medieval and early modern philosophers as meaning that human powers (intellect and will) are modeled on divine ones. Cf. Clines (1968); Perler and Schierbaum (2014: 34-36).
} 
that, just as there are non-free and free kinds of volitions as regards the human will, one can distinguish between divine states of desiring that are constantly (and necessarily) actualized, and free activities of divine will. ${ }^{54}$ By the latter, "something is produced or the state of an existing thing is changed." 55 God caused the world by means of such a free activity. ${ }^{56}$ Crusius has an argument for this. It that can be paraphrased as follows:

1. Some actions, that is, actualizations of powers (call them "first actions"), are such that (a) they do not constantly occur and (b) if their conditions are met, the efficient cause having the power to produce such actions can either perform an action A, or omit A, or perform some action B (at one and the same time) as long as no contradiction arises. ${ }^{57}$

2. God's action of causing the world was such a "first action," since

3. neither could the world have existed before its creation

4. nor could it have been created from eternity,

since this would imply the following contradiction:

5. the world is eternal (such that there is no cause of the world prior to it) and the world is created (such that there is a cause of the world prior to it).

6. Therefore, God created the world freely, that is, in a way such that He could also have not created the world at all, or could have created at least a different world. ${ }^{58}$

Again: the world, that is, the whole of all concrete particulars that can causally interact in temporal succession, ${ }^{59}$ is contingent and the world's being contingent implies that the act of creating it was not necessary, but contingent. ${ }^{60}$ The idea is this: God

\footnotetext{
${ }^{54}$ This gives rise to the objection that this conception of divine freedom is incompatible with God being pure act (actus purus). Crusius seems to be aware of this. Cf. Entwurf $\$ 262,476$. There, he attempts to distinguish between God's power as being part of His immutable essence and His transient actions.

55 "Man sieht aber keinen Grund, andere freye Thätigkeiten in Gott zu statuieren, als solche welche actiones transeuntes sind, und wodurch entweder etwas hervorgebracht, oder der Zustand eines schon existirendes Dinges verändert wird." Crusius, Entwurf §276, 499.

56 These are also called "transient actions" (actiones transeuntes). Crusius, Entwurf $\$ 276,500$.

${ }^{57}$ Note that in this passage Crusius literally says that the action "can be directed in this way or another" ("so und auch anders gerichtet werden können"). The point is that, as stated above, freedom is the power to choose one of the prevailing desires and to make it action-guiding. Therefore, it is a matter of which desire the power is directed at.

58 "Aber es giebt auch noch andere erste Actionen, welche nicht immerfort geschehen, und welche mithin, wenn nur die gehörigen Bedingungen vorhanden sind, von der wirkenden Ursache unternommen und unterlassen, ingleichen so und auch anders gerichtet werden können, so lange kein Wiederspruch entsteht. Dergleichen ist in Gott, z.E. die Action gewesen, durch welche er die Welt hergecht [sic]. Denn ehe Gott die Welt erschuf, kann dieselbe nicht da gewesen seyn, und von der Ewigkeit kann die Welt auch nicht seyn geschaffen worden, welches sich selbst offenbar wiederspräche, weil gesetzet würde, es sey etwas ewig, welches doch etwas anderes vor sich habe, nehmlich die Ursache, von welcher es hervorgebracht worden.” Crusius, Vom rechten Gebrauche, Übers. Krause, §25, 71-72.

${ }^{59}$ See "(world $\left.{ }_{\text {act }}\right)$ " above.

60 "Mit dem Zufälligen verhält sich die Sache umgekehrt, nehmlich der Grund der Zufälligkeit liegt darinnen, daß das Zufällige von einer Ursache hervorgebracht werden muß, ohne welches es nicht seyn könnte, und bey deren Veränderung es anders seyn würde. Man verwirre das Zufällige im metaphysischen Verstande (contingens) nicht mit dem Zufälligen im logikalischen Verstande (accidentibus praedicabilibus §30)." Crusius, Entwurf §121, 199-200.
} 
created the world by exerting the power of His will. According to Crusius, there are two kinds of volitional powers - a non-free and a free power. The actualized power involved in the creation of the world cannot be of the non-free kind, that is, it cannot be one of the constantly actualized states of desiring, since it is hard to see how a state that is always actualized in God could have caused the world to exist at $a$ certain point in time. Thus, Crusius concludes, the act of creating the world (causing it to exist) must have involved an actualization of the free power, since such free or "first" acts do not constantly occur, but at a certain point of time-if at all.

Although Leibniz agrees that God created the world contingently, ${ }^{61}$ he rejects Crusius's conception of a sufficient yet not determinant cause and its application to God's power of will. Even more importantly, he rejects Crusius's notion of contingency as it is tied to the latter's conception of freedom. For Leibniz, God necessarily acts for the best reason, since He is the wisest, that is, most rational being. For Leibniz, just as for Crusius, freedom comes in degrees. For Crusius, the point is that a power can be exerted with more or less intensity. Leibniz writes:

The more we act according to reason, the freer we are, and there is so much more servitude the more we act in accordance with the passions. For the more we act according to reason, the more we act according to the perfections of our own nature, and insofar as we allow ourselves to be carried away by passions, we are slaves to external things, which act upon us. [...] For God, being the freest and most perfect substance is also the most determined by himself to do the most perfect. ${ }^{62}$

According to this picture, human actions are never completely free insofar as they are most often influenced by passions and other non-rational elements. Only God is completely exempt from any non-rational influence. The fact that God is perfectly free means that $\mathrm{He}$ is wholly determined by reason. More precisely, $\mathrm{He}$ is determined by the best reason. ${ }^{63}$ Perfect freedom is perfect self-determination, where reason in its highest degree is the determining principle.

As mentioned earlier, God, according to Leibniz, created the best possible world, not just any possible world, since by doing the latter He would have acted less than fully rationally, and thus, less than perfectly. This, however, would contradict His perfection, which implies perfect rationality. In Leibniz's view, then, the following question arises as regards Crusius's account: if God created the world in such a way that He could have created a different world or no world at all, what was His reason for choosing this world? Was it just any reason, or did He, in fact, have no reason at all? In Leibniz's view, the problem would be the same in both cases: both would contradict God's perfection. It should become clear in the next section that the metaphysical credentials of freedom of indifference play a crucial role in Crusius's endeavors to show that divine freedom is compatible with a contingent creation and God's perfection.

\footnotetext{
61 Leibniz holds that the act of creating the world was morally necessary, not metaphysically or logically necessary. See Adams (2005), Pickup (2014) and Rescher (2002).

62 Leibniz, On freedom and spontaneity (after 1690), 2006: 94-95.

63 In my view, his characterization of freedom is merely negative. It amounts to something like being free from non-rational factors. Leibniz is a compatibilist (that is, he holds the view that that freedom is compatible with determinism).
} 


\section{The "Non-futility Argument" and Crusius's Analysis of Ends}

If God, in Crusius's conception, is to be perfectly rational, based on the assumption that we do not live in the best possible world, then Crusius has to provide an alternative divine principle of action. ${ }^{64}$ Such a principle is presented in two different versions or wordings: according to the first, God never acts in vain, that is, in such a way that whatever He does is futile. ${ }^{65}$ According to the second, God never acts without an end (or "against an end"). ${ }^{66}$ How do the two versions relate to one another?

It should be clear that, in the sense relevant in the context of intentional actions, acting without an end (or "against" it) could count as acting in vain, or as doing something futile. This, of course, applies to human actions, which can be, and actually are, less than perfectly rational — and not to divine actions. The point just is that, due to His perfection, it is impossible for God to act without (or "against") an end.

In order to better understand what exactly is at stake here, we must consider the relevant notion of futility and Crusius's analysis of ends. The notion of futility is an ontological notion. In general, something is, ontologically speaking, futile if nothing different from that thing becomes either possible or actual by the thing alone or in combination with other things. ${ }^{67}$ To put it more formally:

(futile) $)_{\text {ont }} \mathrm{x}$ is futile if and only if there is no $\mathrm{y}$ such that $\mathrm{y}$ is possible or actual because of $x$ (or because of $x$ together with $z, \ldots$ ) where $y$ is different from $\mathrm{x}$.

"Futile" in this ontological sense also applies to actions, since they are a kind of thing. It is possible to say that an action is futile (or not futile) and thereby to say something true or false. One difference between divine and human action is that if one says that a human action is futile (or not), one says something contingently true (or false). If one says that a divine action is futile (or not), one says something necessarily true (or false), since God cannot do anything futile, whereas humans can.

"Futile" can also have a different sense, which involves a failed intentional action, that is, an action that brought about something one did not intend to bring about. ${ }^{68}$ For instance, if Peter intended to kiss Anne in order to make her happy, but due to a mistake ended up kissing her twin sister, then he failed to make Anne happy by

\footnotetext{
64 Crusius argues that the notion of the best possible world is equivocal. It could mean that it is metaphysically impossible that any actual world is the best possible world, or that it is impossible to demonstrate that any world is the best possible world. See Crusius, Entwurf $\S \S 385-388$; for a discussion see Caro (2014: 85-100).

65 "Gott kann aber nichts thun, was irgend einmal ganz vergeblich ist." Crusius, Entwurf $\$ 477,934$.

${ }^{66}$ Crusius also calls this the "principle of morally sufficient reason," as opposed to Leibniz's principle of sufficient, that is, determinant reason: "Sic vero elenchus mutatur, neque de principio illo rat. suff. sensu ontologico et physico dicitur, sed de ratione moraliter sufficiente, qua fit, ut Deus nihil sine fine, nihil contra finem, agat." Crusius, De usu §17, fn., 192-193. (My italics).

67 "Das Seyn eines Dinges darf dem Nichtseyn nicht gleich gelten. Demnach muß durch ein iedwedes Ding etwas anderes möglich, oder wirklich werden, es mag nun entweder durch dasselbe allein, oder mit Hinzunehmung mehrerer Dinge möglich, oder wirklich gemacht werden." Crusius, Entwurf §29, 45.

68 Cf. Crusius, Anweisung §104, 124-125.
} 
kissing her. However, he might have made her twin sister happy, however, unintentionally. ${ }^{69}$ In this case, his action was not futile in the purely ontological sense. It is, of course, impossible that there could be any failed action by God. The reason is the same as for why He cannot do anything_ontologically_futile: it would be incompatible with His perfection.

The ontological sense of "futile" is at work in the principle that God cannot do anything futile. This is why it is metaphysically impossible for there to be one single thing in the actual world which would be futile in the ontological sense. The point is that God's free actions are acts of creating (and sustaining) things, that is, substances and their powers. ${ }^{70}$ Crusius states:

... God cannot do anything whose existence would be totally futile at any moment, that is, neither with respect to the thing created nor with respect to Him, so that by (that thing) it would not be the case that anything different from that thing would constantly be made real or possible. ${ }^{71}$

More formally, we can hold:

(futile) $)_{\text {div }}$ A divine action $\mathrm{A}$ is futile if and only if nothing different from A becomes constantly possible or real by $\mathrm{A}$, that is, either in relation to the thing created by $\mathrm{A}$, or in relation to the divine agent.

How are we to take the two relational specifications here-(a) with respect to the thing created and (b) with respect to the divine agent? In order to answer this, we must turn to Crusius's analysis of ends. Intentional actions, divine or human, are determined by their ends. An end is, in the widest sense, "what a mind wills."72 Crusius adds that, in the proper, or narrower, sense, to will something as an end implies to will it "consciously and with distinct knowledge."73 Free intentional actions require reason, as Crusius repeatedly emphasizes. ${ }^{74}$ An end has three components which make up one complete end. Crusius also speaks of the "end's integrity."75

Whenever an agent consciously and knowingly wills to do something for the sake of an end, these three components are involved: (i) an actual state of desiring (this is called the "subjective end"), (ii) an object of this actual state of desiring

\footnotetext{
69 For a classical account of intentional action, see Anscombe (1957).

70 On the aspect of sustaining creation, see Crusius, Entwurf $\$ 329,611 \mathrm{f}$.

71 “... daß Gott nichts thun kan, dessen Daseyn überhaupt, oder in Ansehung seiner irgend einmal ganz vergeblich seyn würde, so daß dadurch nicht beständig etwas anderes wirklich oder möglich gemacht würde." Crusius, Entwurf $\$ 281,505$. (My italics).

72 "Dasjenige, was ein Geist will, kan man in dem weitesten Verstande eine Absicht oder ein Endzweck nennen." Crusius, Anweisung $\$ 13,15$.

73 "In der engern Bedeutung [...] verstehet man unter einem Endzwecke nur etwas, was man mit Bewustseyn und deutlicher Erkenntnis will." Ibid.; See also Crusius, De appetitibus, §LXIX, 136 "Sed quotiescunque libere agimus, finis cuiusdam nobis conscii esse necesse habemus."

74 Cf. Crusius, Entwurf $\$ 322,597 ;$ \$335, 622; §449, 877. Anweisung §5, 7; §45, 56.

75 “... daß der göttliche Zweck bey der Schöpfung auch als ein Zweck seine Integrität haben müsse.” Crusius, Entwurf $\$ 354$, p.669. (My italics). Crusius uses the terms "end" (Zweck), "final end" (Endzweck) and "intention" (Absicht) interchangeably. Cf. Cruisus, Anweisung §13, 15.
} 
("the objectual end") and (iii) some relation the action is taken to establish between the subject and the desired object (the "formal end"). Crusius gives the example of Alexander the Great, who went to war against the Persian Empire. In this case, (i) Alexander's desire was to rule ("subjective end"), (ii) the object of his desire was the Persian Empire ("objectual end") which (iii) he wanted to bring under his command by going to war ("formal end"). ${ }^{76}$

This analysis also applies to the ends of God's action of creating the world. Crusius has no difficulties in identifying God's integral end of creating the actual world. As to (i), the state of desiring, Crusius identifies it as God's "longing for perfection and for love and goodness." necessarily actualized in God, since it is part of the non-free and necessary kind of willing. ${ }^{78}$

(ii) The object of God's desire is the world, which, before it was created, existed as something that was possible in God's mind. ${ }^{79}$ Among all things that are created, free rational minds play a privileged role, since they are the "final objectual end" of creation. ${ }^{80}$ Why is that? The problem with divine action is that there cannot be any action by means of which God's perfection could be increased, since His perfection is infinite. ${ }^{81}$ So why should God, according to this picture, act at all, given that His actions will make no difference with respect to God himself and His divine properties? Referring to divine goodness, as Leibniz seems to do, will not suffice for solving the problem that-according to Crusius's analysis of ends-there seems to be no proper reason for God to create the world at all. The problem is that creating the world neither increases His power, wisdom or goodness, nor His knowledge of them. ${ }^{82}$ Crusius's answer is that-although God cannot act in order to add anything to, or qualitatively "improve," His essential properties-He can nevertheless act in order to add something in relation to Him.

The point is that (iii) the formal end of creation is something that can only be established by free rational creatures: God wants rational agents to freely act in accordance with what He has determined to be (morally) good. ${ }^{83}$ The formal end of

\footnotetext{
76 "Z.E. als Alexander den Feldzug wieder die Perser vornahm, so war das Persische Reich der objektivische Zweck. Der formale Zweck war, daß er dasselbe unter seine Bothmäßigkeit bringen und beherrschen wolte. Die Herrschsucht Alexanders aber war der subjektivische Zweck." Crusius, Anweisung §13, 15.

77 "Es bleiben also vor den göttlichen Willen nur zwey Grundverlangen oder Grund-Begierden übrig, nemlich das Verlangen der Vollkommenheit und die Liebe und Gütigkeit, aus welchen wiederum viele andere Eigenschaften fliessen." Crusius, Entwurf \$277, 501. See also his Entwurf \$354, 669-670: "Der subjektivische Zweck muß in denen göttlichen Grund-Verlangen liegen, und muß also etwas seyn, welches mit denen göttlichen Verlangen der Vollkommenheit und mit seiner Güte zusammen hänget.”

78 See Sect. 4.

79 Concerning this point, Crusius seems to agree with Leibniz. Leibniz holds that all possible beings exist in God's mind. See Leibniz, Théo., §255; Discours Métaphysique, §14; cf. Joráti (2017).

${ }^{80}$ Da nun aber die Freyheit die Vernunft voraussetzet, so müssen die letzten objektivischen Endzwecke Gottes bey der Schöpfung vernünftige und freye Geschöpfe seyn.” Crusius, Entwurf \$354, 670.

81 Cf. ibid.

82 Cf. Crusius, Entwurf $\$ 281,507$.

83 “... daß durch die Thätigkeiten der Creaturen in so fern, wie fern sie nicht von seiner eigenen Schöpfung und Bestimmung abhangen, gewisse Verhältnisse gegen ihn möglich werden, welche mit seinen
} 
creation is that rational agents freely obey the natural law implemented by God. It is a matter of relation insofar as the fact that rational agents act freely and, in accordance with God's wishes, sometimes even morally, affects their relation to God as their "overlord." If rational agents were determined to act in accordance with this natural law, it would make no difference whether they existed as possible beings in God's mind or as actual creations of God: His relation to them would be the same with respect to their actions, since in both cases God would be the one who determined them. This does not apply to free actions, since it is only their possibility that wholly depends on God insofar as He created freedom as a power.

Crusius provides an argument by means of which he wants to establish that there actually are free (human) actions. They are the formal end of creation. The "nonfutility" argument runs as follows:

1. If a concrete particular $p$ is not free or is not the effect of a free action, then God is the determinant cause of $p$.

2. If God were the determinant cause of every concrete particular $\left(p_{1}, p_{2}, p_{3}, \ldots p_{\mathrm{n}}\right)$, then the relation between God and all particulars $\left(p_{1}, p_{2}, p_{3}, \ldots p_{\mathrm{n}}\right)$ would be the same before and after the particulars were created: all particulars would be totally dependent on God in both cases.

3. Thus, if all particulars (= the whole world) were totally dependent on God, whether possible or actual, then there would be no formal end of God's act of creating the world, that is, there would never be any relation between any of the particulars and God that did not obtain before creation.

4. However, it is contradictory to God's perfection that He could act without a formal end. ("God never acts without an end").

5. Free actions of human substances are the formal end of creation, since only the power of freedom, not its actualization, wholly depends on God.

6. God created the world.

7. Therefore, there are free actions of human substances. ${ }^{84}$

The formal end of divine action requires that it can establish something that (a) did not exist before and (b) that-in some respect-does not totally depend on God. The latter can only be an agent who can act freely, but in accordance with natural law: this is what God desires free agents to accomplish due to His perfection.

By the "non-futility argument," Crusius wants to establish that we are free in this way. At least this argument is non-circular: recall that I mentioned in the Introduction that Ockham, another voluntarist, even doubts the possibility of arguing for the existence of freedom of indifference in a non-circular way. What is more, Crusius provides a metaphysical reason for why there is freedom of indifference in any actual world as a matter of hypothetical necessity. In other words, he provides a

Footnote 83 (continued)

Eigenschaften übereinstimmen. Dieses geschieht, wenn freye Geschöpfe in der Welt sind." Crusius, Entwurf $\$ 281,506$.

84 See Crusius, Entwurf $\$ 281,504-508$. 
reason why the conditional, if there is a world, then there is freedom of indifference, necessarily holds: because it is metaphysically impossible that there be any futile divine action in the previously explained sense.

Of course, you may not find this argument very convincing and the metaphysical assumptions it rests upon questionable and obsolete. They can be seen, however, as part of Crusius's attempt to bestow some metaphysical value or dignity upon the freedom of indifference. ${ }^{85}$

\section{Conclusion}

My aim in this paper was to make plausible the claim that Crusius's metaphysical argument for the hypothetical necessity of freedom of indifference can be interpreted as an attempt to bestow some metaphysical value or dignity upon this kind of freedom. In the history of philosophy, it has been suspected of favoring and promoting the possibility of acting "outside the bounds of reason," as McCord Adams puts it $(1999,266)$. Crusius, however, makes it very clear that this kind of freedom necessarily presupposes rationality. ${ }^{86}$ The fact that people can freely act against their rational insights merely affirms what experiences teaches us. But it neither shows that one is allowed to act stupidly, nor that one should act in that way. ${ }^{87}$

If Crusius's argument, as reconstructed here, were successful, he could maintain that, although we might not live in the best of all possible worlds, our freedom of indifference carries the metaphysical weight of being the one indispensable ingredient of any actual world. It is no coincidence, of course, that according to the "image" thesis, ${ }^{88}$ the most important and "superb" aspect in which man is made in the image of God, is freedom of indifference. Only a creature that has that power can-at least to some extent-act independently of its maker. ${ }^{89}$

According to this picture, the relation between rational and free agents and the divine agent is one of total ontological dependence, but the moral dependence of rational agents has a clearly voluntary element: becoming a moral agent and thus perfecting oneself is not simply, as Leibniz claims, a matter of merely removing the obstacles to rational self-determination, but a matter of actively and positively taking a step in the morally "right" direction. It is literally up to us whether we comply with the divine wish to see us act morally (Figs. 1, 2).

Besides its metaphysical value as a hypothetically necessary element of any actual world, freedom of indifference allows us to actively make a difference in this world on the basis of the available reasons - and not just by making sure that the determining power of reason can do its work unimpeded. In the end, the difference between the rationalist's and the voluntarist's approach could be framed in terms of

\footnotetext{
85 See Introduction.

86 Crusius, Anweisung \$45, 55-56.

87 Crusius, De usu §17, 193.

88 See above, fn.53.

89 See quote in fn. 42 .
} 


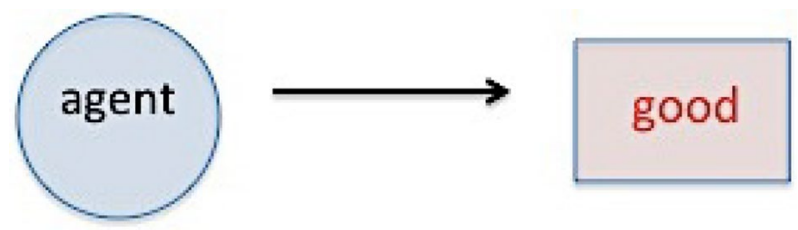

Fig. 1 Picture of the voluntarist: the rational agent has to actively take a step toward the morally good

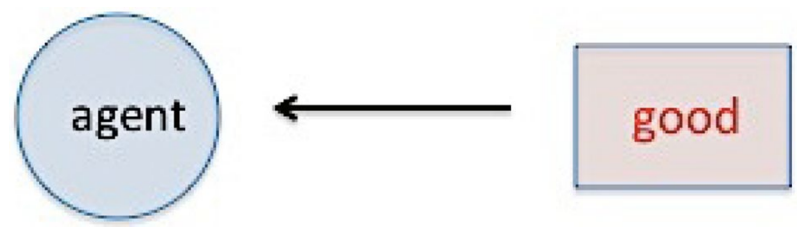

Fig. 2 Picture of the rationalist: the rational agent has to remove any obstacle to the determining power of reason by which he knows what is morally good

the agents' own activity or passivity concerning their attempt at doing what is morally right (or wrong). ${ }^{90}$ The voluntarist has to actively embrace what she recognizes to be good in order to let reason become effective. By contrast, the rationalist has to make sure that nothing impedes reason's insight into what is good (and right). She has to let her action be determined by what is good. Although the voluntarist's approach might, in some sense, imply as real the possibility of acting less than perfectly rational, it also implies a kind of independence or autonomy that values the agent's own activity at least as much as rationality.

Acknowledgements Funded by the Deutsche Forschungsgemeinschaft (DFG, German Research Foundation) Project Number: (SCHI 1317/2-1).

Open Access This article is distributed under the terms of the Creative Commons Attribution 4.0 International License (http://creativecommons.org/licenses/by/4.0/), which permits unrestricted use, distribution, and reproduction in any medium, provided you give appropriate credit to the original author(s) and the source, provide a link to the Creative Commons license, and indicate if changes were made.

\section{References}

Adams, Robert M. 1994. Leibniz-Determinist, Theist, Idealist. Oxford; New York: Oxford University Press.

Adams, Marilyn McCord. 1999. Ockham on Will, Nature, and Morality. In The Cambridge Companion to Ockham, ed. Paul Vincent Spade, 245-272. Cambridge: Cambridge University Press.

\footnotetext{
90 Cf. Chang (2013). Chang is, according to herself, one of the few contemporary voluntarists. In the context of the normativity of the source of reasons, she suggests framing the discussion in terms of the activity or passivity of the agent rather than in terms of the usual framework of internalism versus externalism. My suggestion to frame the distinction between voluntarists and rationalists in terms of the agent's activity or passivity draws its inspiration from Chang.
} 
Adams, Robert M. 2005. Moral Necessity. In Leibniz-Nature and Freedom, eds. Donald Rutherford and J.A. Cover, 181-193. Oxford; New York: Oxford University Press.

Anscombe, Elizabeth. 1957. Intention. Oxford: Basil Blackwell.

Blumenfeld, David. 1995. Leibniz's Ontological and Cosmological Arguments. In The Cambridge Companion to Leibniz, ed. Nicolas Jolley, 353-381. Cambridge: Cambridge University Press.

Burkhardt, Hans. 1988. Modalities in Language, Thought and Reality in Leibniz, Descartes and Crusius. Synthese 75: 183-215.

Caro, Hernán D. 2014. The Best of All Possible Worlds? Leibniz's Optimism and Its Critics 1710-1755. PhD-thesis. HU-Berlin, edoc-server.

Chang, Ruth. 2013. Grounding Practical Normativity: Going Hybrid. Philosophical Studies 164: $163-187$.

Clines, D.J.A. 1968. The Image of God in Man. Tyndale Bulletin 19: 53-103.

Crusius, Christian August. 1969 [1767]. Anweisung, vernünftig zu leben, darinnen nach Erklärung der Natur des menschlichen Willens, die natürlichen Pflichten und allgemeinen Klugheitslehren im richtigen Zusammenhange vorgetragen werden, hrsg. v. Prof. Dr. Giorgio Tonelli, Bd. 1. Hildesheim: Georg Olms Verlagsbuchhandlung.

Crusius, Christian August. 1987 [1742]. Dissertatio philosophica de appetitibus insitis voluntatis humanae. Leipzig. In Christian August Crusius, Kleinere philosophische Schriften Teil 1, eds. Sonia Carbonici, Reinhard Fister. Hildesheim; Zürich: Georg Olms Verlag.

Crusius, Christian August. 1987 [1743]. Dissertatio philosophica de usu et limitibus principii rationis determinantis, vulgo sufficientis. In Christian August Crusius, Kleinere philosophische Schriften Teil 1, eds. Sonia Carbonici, Reinhard Fister. Hildesheim: Georg Olms Verlagsbuchhandlung.

Crusius, Christian August. 1744. Ausführliche Abhandlung von dem rechten Gebrauche und der Einschränkung des sogenannten Satzes vom zureichenden Grunde. Aus dem Lateinischen übers. u. mit Anmerkungen nebst einem Anhange begleitet von Christian F. Krausen. Leipzig.

Crusius, Christian August. 1964 [1745]. Entwurf der nothwendigen Vernunft-Wahrheiten, wiefern sie den zufälligen entgegen gesetzet werden. In Die philosophischen Hauptwerke, ed. Prof. Dr. G. Tonelli, Bd. 2. Hildesheim: Georg Olms Verlagsbuchhandlung.

Dyck, Corey. (forthcoming). Power, Harmony, and Freedom: Debating Causation in 18th Century Germany. In Oxford Handbook of Eighteenth Century German Philosophy, eds. Frederick Beiser and Brandon Look. Oxford: Oxford University Press.

Greenspan, Patricia. 2012. Free Will and Rational Coherence. In Action Theory (Philosophical Issues 22), eds. E. Sosa and E. Villanueva, 185-200. Boston, MA: Blackwell.

Griffin, Michael V. 2012. Descartes' Arguments for the Existence of God. In Id., Leibniz, God and Necessity, 9-33. Cambridge: Cambridge University Press.

Hogan, Desmond. 2009. Three Kinds of Rationalism and the Non-Spatiality of Things in Themselves. Journal of the History of Philosophy 47(3): 355-382.

Joráti, Julia. 2017. Gottfried Leibniz. In Routledge Companion to Free Will, eds. M. Griffith, N. Levy, and K. Timpe, 293-302. New York: Routledge.

Künne, Wolfgang. 1983. Abstrakte Gegenstände. Semantik und Ontologie. Frankfurt/M.: Suhrkamp.

Leibniz, G. W. 2006. On Freedom and Spontaneity (after 1690) In SLT=The Shorter Leibniz Texts, transl. by L. Strickland. New York: Continuum.

Leibniz, G. W. 1998. Monadology. In G.W. Leibniz. Philosophical Texts, transl. and ed. by R. Francks and R.S. Woolhouse. Oxford: Oxford University Press.

Leibniz, G. W. [1680, $\left.{ }^{4} 1684\right]$ 2002. Principes de la nature et de la grâce. In Monadologie und andere metaphysische Schriften, übers., hrg. u mit einer Einleitung, Anmerkungen und Registern versehen von Ulrich Johannes Schneider. Hamburg: Meiner.

Leibniz, G. W. [1710] 1996. Versuche in der Theodicée über die Güte Gottes, die Freiheit des Menschen und den Ursprung des Übels, übersetzt und mit Anmerkungen versehen von Artur Buchenau. Hamburg: Meiner.

Leibniz, G. W., Brandon Look, and James H. Stam eds. 2005. Confessio Philosophi: Papers Concerning the Problem of Evil, 1671-1678. New Haven; London: Yale University Press.

Ockham, William of. 1980. Quodlibeta septem. Opera Theologica IX, ed. J. C. Wey and St. Bonaventure. NY: The Franciscan Institute.

Perler, Dominik, Sonja Schierbaum eds., transl., comm. 2014. Selbstbezug und Selbstwissen. Texte zu einer mittelalterlichen Debatte. Frankfurt a.M: Klostermann. Rote Reihe Bd. 71.

Parkinson, George H. R. 1970. Leibniz on Human Freedom. Studia leibnitiana, Sonderheft 2. 
Pickup, Martin. 2014. Leibniz and the Necessity of the Best Possible World. Australasian Journal of Philosophy 92(3): 507-523.

Rescher, Nicholas. 2002. Leibniz on God's Free Will and the World's Contingency. Studia Leibnitiana 34(2): 208-220.

Schneewind, J.B. 1998. The Invention of Autonomy. A History of Modern Moral Philosophy. Cambridge: Cambridge University Press.

Sonja Schierbaum Ph.D. (2012), University of Hamburg, has worked as a postdoctoral researcher at the Humboldt-University, Berlin. She has published several articles in journals such as Vivarium and coauthored a volume on the medieval conception of self-knowledge with Dominik Perler. Her research project "Practical Reasons Before Kant (1720-1780)" was recently admitted to the Emmy Noether-programme of the German Research Foundation. 